\title{
DESEJOS DE MEMÓRIA PROCEDIMENTOS DE RECRIAÇÃO DE COREOGRAFIAS DE EVA SCHUL
}

Mônica Dantas

Doutorado pela Universidade do Québec, em Montréal, Canadá (2008). Professora Adj. Da Universidade Federal do Rio Grande do Sul, Brasil. 
Resumo: Apesar do aperfeiçoamento das formas de registro e veiculação dos produtos coreográficos em diferentes mídias e das possibilidades de se fazer dança em outros suportes para além do corpo, pensamos que o ato de dançar é ainda uma das melhores maneiras de celebrar a dança e sua memória. Neste artigo, temos por objetivo refletir sobre os procedimentos de recriação utilizados no Projeto Dar carne à memória, realizado em Porto Alegre em 2010 e que teve por propósito tornar disponível uma parte do repertório de dança contemporânea criado no sul do Brasil, através da recriação de coreografias de Eva Schul de diferentes períodos. Quais foram os procedimentos recorrentes? Qual foi o papel da coreógrafa, dos bailarinos, dos demais colaboradores nesse processo? Como nos posicionamos em relação aos binômios autenticidade/interpretação e reconstrução/recriação? Respondendo a essas questões, esperamos contribuir para traçar estratégias para criação e manutenção de repertórios de dança contemporânea e, ao mesmo tempo, continuar a celebrar a memória da dança contemporânea em Porto Alegre.

Palavras-chave: Recriação coreográfica - Memória da dança contemporânea - Eva Schul

Abstract: In spite of the improvement of the forms of registration and divulgation of choreographic products in different media and the possibilities of making dance in other supports beyond the body, we think that the act of dancing is still one of the better ways to celebrate dance and its memory. In this article, we intended to reflect on the re-creation procedures used in the Project Dar carne à memória, carried 
out in Porto Alegre in 2010 and whose purpose was to make available a part of the contemporary dance repertoire created in southern Brazil, by means of the re-creation of choreographies by Eva Schul from different periods. What were the recurrent procedures? What was the role of the choreographer, the dancers, and the other collaborators in that process? How did we stand in relation to the binomials authenticity/interpretation and reconstruction/re-creation? By responding to these questions, we hope to contribute to devise strategies for the creation and maintenance of contemporary dance repertoires and, at the same time, continue to celebrate the memory of contemporary dance in Porto Alegre.

Keywords: Choreographic re-creation - Memory of contemporary dance -Eva Schul 


\section{Introdução}

Apesar do aperfeiçoamento das formas de registro e veiculação dos produtos coreográficos em diferentes mídias e das possibilidades de se fazer dança em outros suportes para além do corpo, o ato de dançar tem sido ainda uma das melhores maneiras de celebrar a dança e sua memória. Como destaca Thomas (2003), desde meados dos anos 1980 há um crescente interesse na reconstrução e/ou recriação de obras coreográficas representativas dos primeiros períodos da dança moderna. Nos Estados Unidos, nos anos 1970, Annabelle Gamson recriou solos de Isadora Duncan ${ }^{1}$ e, posteriormente, de Mary Wigman². Entre os anos 1970 e 1980, Ernestine Stodelle reconstrói coreografias solo de Dóris Humphrey, como Two Ecstatic Themes (1931) e The Call/Breath of Fire (1929/30). Lesley Main, desde 1995, dedica-se a remontar coreografias de grupo de Doris Humphrey, como Water Study (1928), The Shakers (1931), With My Red Fires (1936) e Passacaglia (1938). Na Alemanha, em 1987, Susanne Linke dança Affectos Humanos, quatro solos criados por Dore Hoyer em 1962.

Em 2000, na França, o Quatuor Albrecht Knust apresenta D’un faune (éclats), releitura de L'après midi d'un faune (1912), de Vaslav Nijinski. Em 2001, o mesmo grupo retoma Continuous Project/Altered Daily (1970), de Yvonne Rainner e Satisfying Lover (1968), de Steve Paxton, propondo releituras de projetos desenvolvidos por artistas da chamada dança pós-moderna (BANNES, 1987).

Quatuor Albrecht Knust propunha um acesso às obras através de registros escritos, atendo-se, principalmente, às notações realizadas no Sistema Laban.

Atualmente intensificam-se as pesquisas e eventos dedicados à memória da dança moderna e contemporânea. Em 2008, Dominique Brun, que havia integrado o Quatuor Albrecht Knust, cria Siléo, uma peça composta pelo cruzamento entre um texto contemporâneo de Wajdi Mouawad e coreografias criadas entre os anos 1930 e 1940 por Valeska Gert, Kurt Jooss, Dore Hoyes, Doris Humphrey e Mary Wigman.

\footnotetext{
$1 \quad$ Os solos de Isadora Duncan foram Water Study (música de Schubert), Five Waltzes (música de Brahms), Dance of the Furies (música de Gluck), Études (música de Scriabin). Não foi possível identificar as datas de estreia dessas danças.

$2 \quad$ Pastorale (1929), Hexentanz (1913/14), Summer Dance (sem identificação de data de estreia).
} 
Em 2011, Olga de Soto apresenta um projeto de releitura da Mesa Verde (1932), obra seminal de Kurt Jooss. Esse dois projetos, assim como outros, incluem uma extensa pesquisa de documentação e criação, a partir da qual o processo de recriação é compartilhado com o público, através de ações como conferênciasdançadas, exposições, etc. Ou seja, não é somente o produto final - a coreografia recriada - que é tornada pública.

No Brasil, ainda são poucos os projetos dedicados a reconstituir obras de coreógrafos brasileiros. Não obstante, em 2007, a Companhia de Dança da Cidade, no Rio de Janeiro, dirigida por Marise Reis e Roberto Pereira, apresenta Danças de Repertório, espetáculo composto por nove coreografias de oito coreógrafos diferentes $^{3}$, criadas entre 1973 e 1988, que constituem uma pequena mostra da criação coreográfica de matriz moderna e contemporânea no Brasil.

Por outro lado, é importante ressaltar que, se no balé existe uma tradição de manutenção de repertório de obras clássicas, dançadas por companhias de diferentes países, na dança moderna e contemporânea a reconstrução de obras coreográficas e mesmo a manutenção de um repertório geram controvérsias. Há discussões em torno do termo reconstrução, que sugere uma replicação do original, que seria impossível de se atingir porque a dança é uma arte radicalmente incorporada e uma coreografia depende sempre, a cada vez que é dançada, da corporificação e da presentificação de movimentos, gestos, posturas de cada bailarino. Assim, ela não pode ser fixada ou localizada em uma apresentação específica, fato que impossibilitaria a reconstrução fiel de uma obra coreográfica. Em outras palavras, coloca-se em questão os limites e as possibilidades de reconstituição de uma coreografia.

Thomas (2003), analisando o contexto de reconstrução e recriação de coreografias, propõe um continuum no qual, num extremo, encontra-se a noção de autenticidade e, em outro, a de interpretação. A busca de autenticidade implica em

$3 \quad$ As coreografias apresentadas foram: Suíte barroca (1973); de Nina Verchinina; 45 movimentos, Haydn (1976) e 3 minutos com a realidade (1980) de Graciela Figueroa; Sentinela (1983), de Regina Sauer; Busca opus 39 (1985), de Sônia Mota; Boxe (1985), de Renata Melo; Catar (1987), de Lia Rodrigues e João Saldanha; Volúpia (1988), de Ana Maria Mondini (idança.net, 2012). 
reter as condições originais em que a coreografia foi criada. Assim, movimentos, músicas, figurinos, cenários seriam reconstruídos próximos ao modo como foram originalmente concebidos e realizados. Como destaca Main (2005), a reconstrução tem por objetivo a preservação de obras que tenham relevância histórica e ressonância contemporânea, através da restauração de coreografias consideradas perdidas, com o propósito de criar um razoável fac-símile do original.

Aproximando-se dessa abordagem estariam as proposições de Ernestine Stodelle e de Leslye Main com relação às obras de Doris Humphrey, por exemplo. No entanto, Main (2005) reconhece os limites desta tarefa, seja em função da escassez de informações para a reconstrução fiel da obra, seja por acreditar que o trabalho de reconstrução de uma obra coreográfica (a partir de seus traços) só é possível pela intervenção - e consequente modificação - daquele que reconstrói a obra. Para ela, há sempre um trabalho de coautoria em todo processo de reconstrução de uma coreografia, pois a coreografia e o trabalho original do coreógrafo só se tornam novamente disponíveis a partir da ação daqueles que se dedicam a sua reconstrução. Nesse sentido, todos os que participam desse processo, incluindo, evidentemente, os bailarinos, são considerados coautores.

A noção de interpretação, localizada no outro extremo da escala, reconhece a impossibilidade de se refazer uma coreografia do modo como foi criada e postula uma relação menos restritiva e mais aberta com as obras originais. Nesse caso, seria mais adequada a utilização de termos como recriação, revisitação, reencenação ou releitura, ao invés de reconstrução. Os projetos do Quatuor Albrecht Knust, por exemplo, são condizentes com essa abordagem. No caso de D'un faune (éclats), os artistas se basearam em uma partitura escrita pelo próprio Nijinski e transcrita, posteriormente, para a notação Laban. A coreografia foi recriada e interpretada por cinco bailarinos. Como ressalta Launay (2001), embora L'après midi d'un faune seja considerada por muitos como pertencente à tradição e ao repertório das companhias de balé, que reivindicam a autenticidade de suas versões, o Quatuor Albrecht Knust vai abordá-la como um dos projetos fundadores da modernidade em dança. A partir dessa perspectiva, em D'un faune (éclats), a 
obra de Nijinski é desconstruída camada por camada, destacando-se do seu criador e se abrindo para novos pontos de partida.

A reconstrução e/ou recriação de obras coreográficas têm interessado tanto a artistas quanto a pesquisadores no âmbito da academia e têm suscitado reflexões relativas a procedimentos artísticos e a abordagens teórico-conceituais. Como ressalta Thomas (2003), as escolhas realizadas para reconstrução/recriação em dança - um evento que desaparece no próprio momento em que se materializa não são apenas de ordem prática, mas são afetadas por concepções históricas, políticas e ideológicas de quem se propõe a essa tarefa. Sendo assim, os projetos de reconstrução/recriação em dança devem andar lado a lado com a desconstrução de discursos e práticas vigentes no campo da história da dança.

Em 2009, em Porto Alegre, propusemos - Eva Schul e eu - o projeto Dar carne à memória. Contemplado com o Prêmio Funarte Klauss Vianna de Dança/2009 e realizado em 2010, o projeto teve por objetivo tornar disponível uma parte do repertório de dança contemporânea criada no sul do Brasil, através da recriação de coreografias de Eva Schul de diferentes períodos. O projeto, organizado em três eixos, propõe três produções diferentes - um espetáculo composto por coreografias de grupo, um espetáculo composto por coreografias solos, além de produções documentais em vídeo e em livro. A partir desse contexto, este artigo tem por objetivo refletir sobre os processos de reconstrução/recriação utilizados no primeiro eixo do projeto Dar carne à memória, que resultou na criação do espetáculo Dar carne à memória I. Quais os procedimentos recorrentes na recriação das obras? Qual o papel da coreógrafa, dos bailarinos, dos demais colaboradores nesse processo? Como nos posicionamos em relação aos binômios autenticidade/interpretação e reconstrução/recriação? Tentando responder a essas questões, esperamos contribuir para traçar estratégias para criação e manutenção de repertórios de dança contemporânea e, ao mesmo tempo, continuar a celebrar a memória da dança contemporânea em Porto Alegre.

\section{Desejos de memória}


Se existem notícias de produções em dança cênica no Rio Grande do Sul desde meados dos anos $1920^{4}$, há uma extensa lacuna no que se refere ao registro e à sistematização da memória da dança cênica no estado. Em relação à dança contemporânea, por tratar-se de um fenômeno relativamente recente, os registros, estudos e propostas de criação de repertórios são ainda mais escassos, embora existam relatos e registros documentais de produções em dança contemporânea no Rio Grande do Sul desde 1974. Além disso, coreógrafos, bailarinos e público guardam em suas memórias as histórias recentes destas danças. Indagamos se esses repertórios de dança criados nas três últimas décadas do século XX já se constituem em pequenas tradições, capazes de referenciar novas abordagens poético-criativas e pedagógicas em dança. Nesse sentido, estamos de acordo com Thomas (2003) quando a autora explica que o conhecimento de nossa herança coreográfica, em termos cinestésicos, visuais e culturais, informa, contextualiza e dá sentido ao trabalho que se faz atualmente em dança. Acreditamos, então, na necessidade de revisitar e de reler as produções coreográficas de décadas anteriores como forma de alimentar a criação coreográfica atual e de revigorar nossos entendimentos sobre a cena contemporânea.

A escolha pelo repertório de uma coreógrafa - Eva Schul - se fez por diferentes motivos. Quando nos referimos a repertório, compreendemos não somente as obras criadas por uma coreógrafa, mas também os procedimentos técnicos, criativos e pedagógicos (ou seja, a poética) que sustentam os processos de realização dessas obras e que se multiplicam e se potencializam em cada pessoa que participa de um ou de todos os momentos destes processos. A trajetória e a obra de Eva Schul justificam plenamente sua escolha para protagonizar este projeto. A coreógrafa foi uma das primeiras a trabalhar sistematicamente com técnicas de dança moderna em Porto Alegre e a utilizar procedimentos de criação

\footnotetext{
4 A monografia realizada por Morgada Cunha e Cecy Franck em 1990 - "Origem, evolução e característica da dança em Porto Alegre" - e publicada sob a forma de livro em 2004 subsidia boa parte dos trabalhos sobre história e memória da dança em Porto Alegre.
} 
baseados em improvisação e composição coletiva, além de constituir ambientes voltados para a prática e a difusão da dança e da arte contemporânea, como o Espaço Mudança, a Ânima Companhia de Dança e o Coda, centro de terapia corporal e dança. Destaca-se também uma prolífica e significativa produção coreográfica, que impactou o cenário da dança contemporânea no Brasil.

Desejar se lembrar não é um ato inocente, como destaca Bernard (2001). Trata-se, antes de tudo, de submeter nossas experiências passadas ao poder de seleção, de reorganização e de transformação e, em consequência, ao poder de embelezamento ou de depreciação que reconstrói e forja um passado à sua imagem. Mas é também crer e fazer crer que essas experiências passadas existem por elas mesmas, que há uma realidade em si dos fatos assim conservados, digna de ser lembrada e reconhecida. O desejo, para Bernard (2001), não somente predetermina a lembrança evocada, mas lhe confere uma materialidade que ele - 0 desejo - pretende corroborar, garantir e confirmar através do discurso que narra essa lembrança. Para o autor, é o discurso quem chancela a memória. Nas suas palavras: "A memória é o produto e a invenção da encenação linguística operada por nosso desejo e por nosso imaginário..." (p. 218).

Assim, desejar se lembrar de uma dança é, com efeito, reduzi-la, a priori, não somente ao fluxo de imagens fugazes e evanescentes que, acredita-se, devem ser lembradas, reconhecidas e enunciadas através de um discurso, mas também é fixála através desse discurso. Como ressalta Bernard (2001), tanto quem deseja se lembrar de um evento coreográfico quanto quem tenta reproduzi-lo em outro momento está condenado a tentar ressuscitá-lo em um tempo necessariamente outro, não somente pelas mudanças das condições históricas, mas também e sobretudo pela transformação da corporeidade que o gera, o reinventa, o apreende e o enuncia.

Não propusemos, portanto, um projeto sobre memória da dança ancorado na ideia de preservar, fixar ou proteger as obras coreográficas da deterioração ou da transformação. Ao contrário, nosso desejo de memória nos levou a pensarmos em ações artísticas que pudessem revisitar, reler, indagar, recriar, reescrever essas 
danças, celebrando, assim, um conjunto de propostas coreográficas significativas para a afirmação da dança contemporânea no Rio Grande do Sul e no Brasil.

\section{Ações poéticas para dar carne à memória}

Como dizíamos no início do artigo, acreditamos que dançar é uma das melhores maneiras de celebrar a dança e sua história. Dançar, para se constituir memórias da dança. Como diz Trisha Brown (citada por Michele e Ginot, 1998), "[...] a criação em dança é recriação de um impulso liberado; é um ato de dar carne à memória do primeiro ato". Dançar é dar carne à memória do primeiro ato para tentar recuperar no movimento algo do sentido e da intenção com que ele foi criado. Nesse projeto, um processo de dar carne a um gesto, sequência, coreografia com alguma pré-existência. Dizemos alguma, porque alguns são traços, registros mais claros, mais nítidos. Outros, mais sutis, quase apagados. Como nos lembra Izquierdo (1998), "[...] somos indivíduos devido à nossa memória: nossa coleção de lembranças é distinta das demais, é única. Nossa memória pessoal e coletiva descarta o trivial e, às vezes, incorpora fatos reais" (p. 60).

O projeto apresentou três eixos para sua execução, sustentados pela noção de ação poética.

A poética, enquanto campo de estudos, se volta sobretudo às condições de existência da obra de arte e, mais especificamente, à instauração da obra. Valéry (citado por Passeron, 1974) compreende a poética como o estudo dos processos de criação, invenção e composição, bem como a análise das técnicas, procedimentos, instrumentos, materiais, meios e suportes presentes na criação da obra. Para Passeron (1974), "[...] o objeto estudado por Valéry não é o conjunto dos efeitos que provoca uma obra, não é tampouco a obra feita nem a obra por fazer (como projeto), mas é a obra sendo feita" (p. 15). Valéry retoma o sentido de fazer, do grego poïen, presente na poética, postulando que os estudos em poética visam refazer o percurso dos gestos criativos que levam à produção da obra para melhor compreendê-la na totalidade de seu percurso genético. A poética, como método de 
investigação, deve tentar compreender a obra nos seus momentos e nos seus espaços de criação, mesmo quando se trata de uma tentativa de recriação dos momentos de instauração da obra. Desse modo, a compreensão dos processos de instauração de uma obra, quando situados temporalmente podem nos informar sobre sua época.

Em consequência, entendemos poética também como o conjunto de referências de que se servem os artistas, consciente ou inconscientemente, para realizar suas obras. São as ideias, concepções, entendimentos que se tem acerca da arte e da vida e que, de certo modo, orientam a concepção e a realização de obras coreográficas. Poética é, igualmente, o conjunto de procedimentos técnicos, formativos e criativos que orientam a concepção e a realização de obras coreográficas (DANTAS, 1999).

A ação poética se dá no jogo entre o que já existe e serve de inspiração para a criação e a recriação coreográfica e o que os artistas de dança desejam e perseguem em cada criação. E também no jogo entre o que está postulado em termos de tradição e a necessidade de invenção. No projeto Dar carne à memória, as ações poéticas são os caminhos utilizados para tentar recriar os gestos - ou seja, os temas, técnicas e procedimentos - de instauração das obras coreográficas.

De acordo com Bernard (2001), o desejo de memória na dança pode se efetivar através de cinco artifícios diferentes: notação coreográfica, fotografia, vídeo, cinema, testemunhos orais e/ou escritos. O que Bernard (2001) chama de artifício, Manning (citada por Main, 2005) chama de traços e Main (2005), de fragmentos de evidências. Em nosso projeto, são ferramentas para a realização das ações poéticas. Utilizamos, principalmente, fotografias, vídeos, documentos escritos e testemunhos orais e impressões cinestésicas e visuais da coreógrafa e de bailarinos que haviam participado da criação das coreografias. Nenhuma obra possuía registro em sistema de notação. 
Descrevemos, a seguir, o processo de recriação das três coreografias que compuseram o espetáculo Dar carne à memória I, localizado no primeiro eixo do projeto.

\section{Dar carne à memória l: ações poético-pedagógicas em processos coletivos}

Este eixo compreendeu a recriação de obras coreográficas de três períodos distintos: Um Berro Gaúcho (1977); Hall of Mirrors (1986); Catch ou como segurar um instante (2002). Essas coreografias são representativas de diferentes momentos da obra de Eva Schul. Dar carne à memória I trabalhou com jovens bailarinos, pois, através da incorporação desse patrimônio técnico e poético, pretendemos colaborar no processo de formação e no aperfeiçoamento de artistas de dança em Porto Alegre. Ao mesmo tempo, desejamos pensar sobre as semelhanças e diferenças entre os processos originais e as recriações da obras: a ideia era experimentar com pessoas com formações diversas, que desejassem dar carne a essas memórias, especulando sobre a recriação dessas obras em corporeidades talvez tão distintas daquelas dos anos 1970 e 1980. Os bailarinos foram selecionados através de análise de currículo, carta de intenções e audição.

As ações poético-pedagógicas iniciaram com aulas de dança contemporânea com Eva Schul, para se estabelecer uma base comum de gestual para os laboratórios de recriação coreográfica, seguindo os princípios desenvolvidos pela coreógrafa ao longo do tempo.

A minha técnica é o trabalho de movimentos fluídos com uso mínimo de esforço, aliada ao conceito da Gestalt e à técnica de improvisação de contato, onde os encaixes dos apoios dos corpos possibilitem a eliminação desses esforços desnecessários, e na improvisação como base da composição coreográfica. Acredito que a empreitada do treinamento da dança não seja um evento simples 
ou singular e sim um investimento de toda a vida no enriquecimento pessoal. A técnica não pode ser limitada à proficiência, mas deve incluir improvisação, criatividade e habilidades coreográficas e de performance. É ainda o estudo de uma perspectiva, uma linguagem para se abordar qualquer estilo de movimento de maneira profunda e enriquecedora para apropriar a experiência do movimento, conectando mente e corpo, usando a respiração como suporte, preenchendo o movimento com intenção e observando a iniciação do movimento e o percurso percorrido através do corpo. Portanto, para mim o bailarino deve ter um corpo muito consciente e fluído e experiência em improvisação e composição. (SCHUL, 2007).

Um aspecto importante da poética, Eva Schul refere-se, justamente às aulas de dança ministradas por ela. Desde o início da sua trajetória, os trabalhos como professora e como coreógrafa são complementares e as aulas são uma importante referência durante os processos de criação coreográfica, pois tornam-se parte do repertório técnico dos bailarinos, estabelecendo um terreno em comum para as improvisações e composições de movimento realizadas pelos intérpretes. Mesmo compreendendo a importância de estabelecer esse terreno em comum, as aulas não tiveram por função recuperar uma corporeidade original que possibilitasse a reconstrução das obras. Em primeiro lugar, porque a formação dos bailarinos atualmente é muito diferente daquela de décadas anteriores. Atualmente, a formação de intérpretes em dança passa pelo estudo de diferentes técnicas de dança e de outras práticas corporais (esportes e lutas, técnicas teatrais, práticas em educação somática, etc.), pelo trabalho com diferentes coreógrafos e pela autoria e coautoria de obras coreográficas (DANTAS, 2005). Em segundo lugar, porque a abordagem técnica de Eva Schul foi-se modificando ao longo do tempo e seu ensino da dança está voltado à formação de bailarinos contemporâneos. Esse pressuposto já localiza nosso projeto numa proposta de recriação de obras coreográficas e não de reconstrução. Do mesmo modo, nos afasta do ideal da autenticidade, pois 
vislumbramos que há sempre um trabalho de transformação e interpretação quando da execução de uma coreografia.

Os laboratórios de recriação incluíram experimentações dos princípios de movimento próprios a cada obra; reconstrução e/ou reelaboração de células e sequências coreográficas; recriação das concepções coreográficas subjacentes a cada obra; recriação e elaboração de figurinos e do desenho de luz. As aulas e os laboratórios de recriação, dirigidos por Eva Schul, foram intercalados com testemunhos orais e discussões sobre as obras e seus contextos. Contaram ainda com a colaboração de Sofia Schul ${ }^{5}$, que, trabalhando com jogos teatrais, buscou dar um sentido de coletividade ao grupo. Ela trabalhou também como assistente de direção em Um Berro Gaúcho e Hall of Mirrors. Como lembra Eva Schul,

O processo na criação, e na recriação, inicia pela pesquisa sobre o tema a ser abordado. A seguir, um profundo debate sobre a questão com todos os envolvidos na criação da obra, ou seja, direção, bailarinos, música, equipe técnica (luz, cenário, figurino), todos criadores na obra. Assim, o coreógrafo ou diretor, será responsável por dar os caminhos das pesquisas práticas e pela condução de todos e do resultado final para a realização do diálogo concreto sobre o tema com o público (SCHUL, 2007).

Houve diferenças nas informações que foram utilizadas para a remontagem das obras, pois algumas deixaram traços mais rarefeitos no que tange aos registros coreográficos e suas possibilidades de recriação. Foi o caso de Um Berro Gaúcho, que possuía registro musical preservado e registros iconográficos, fotográficos e documentais disponíveis, mas nenhum registro em filme ou vídeo.

\footnotetext{
5 Sofia Schul, 23 anos, é atriz e licenciada em teatro pela Universidade Federal do Rio Grande do Sul. A segunda dos três filhos de Eva Schul, nasceu em Curitiba.
} 
Um Berro Gaúcho, baseada na lenda do Sepé Tiarajú, retoma o tema da busca de uma identidade regional vinculada a uma perspectiva urbana, com ecos da contracultura. A trilha musical foi especialmente composta, nos anos 1970, por Toneco e Carlinhos Hartlieb. A remontagem dessa coreografia seguiu uma metodologia de recriação fundamentada na improvisação como base da composição coreográfica. Os temas para as improvisações se definiram a partir destes registros. Esta versão da coreografia, embora bastante diferente em sua movimentação e gestualidade, manteve alguns personagens e a estrutura das cenas. Dezesseis bailarinos recriaram e interpretaram a coreografia.

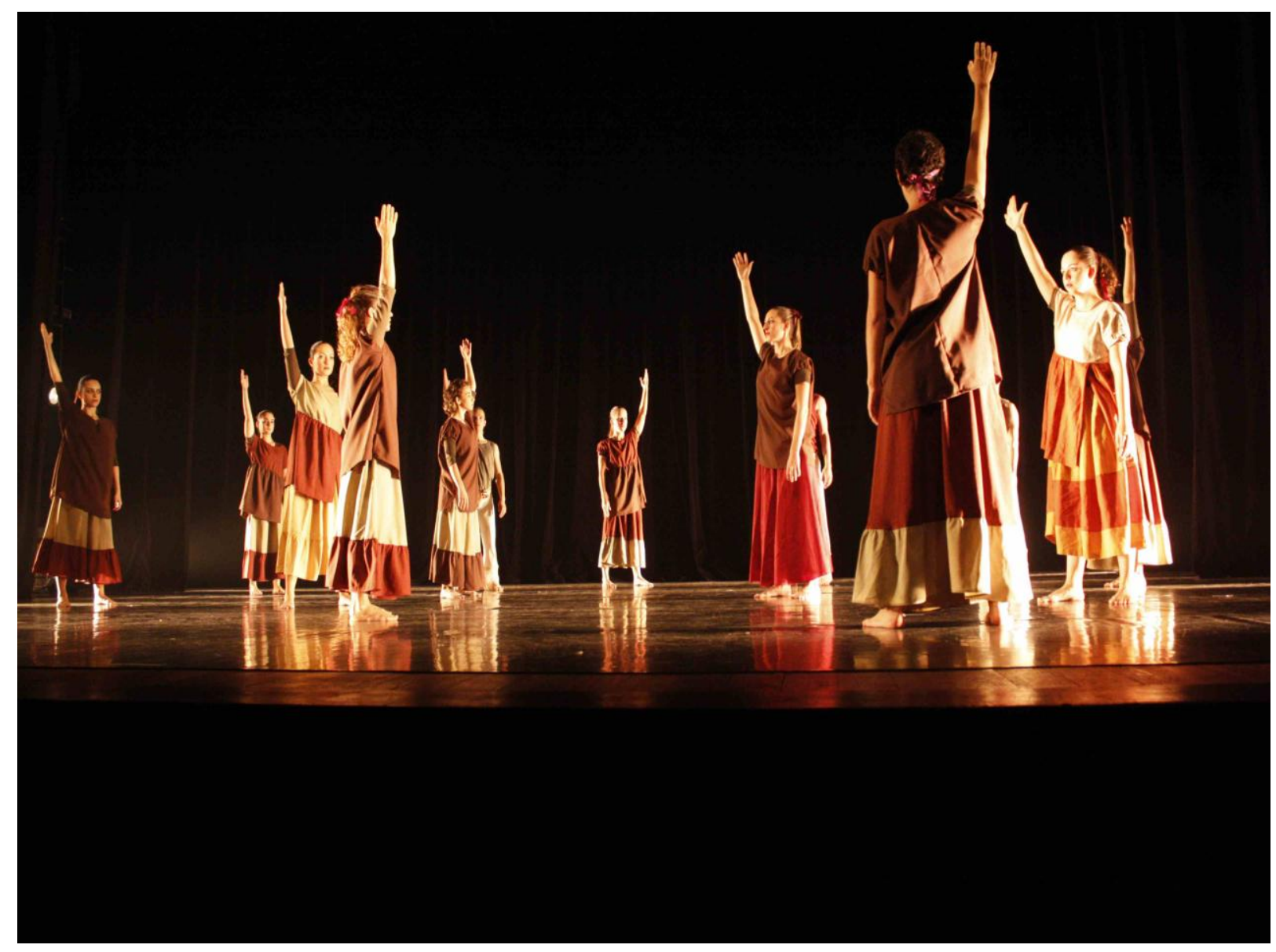

Um berro gaúcho, coreografia de Eva Schul. Projeto Dar carne à memória. Fotografia: Sofia Schul. 
Bernard (2001) reflete sobre os limites da utilização da fotografia e dos testemunhos orais e escritos como estratégias para se reavivar a lembrança de uma coreografia, pois ela neutraliza a temporalidade do movimento real. Longe de memorizar a dança, a vontade de fotografá-la não ultrapassa o reflexo do olho que tenta surpreende-la e fixá-la. No caso de Um Berro Gaúcho, as fotografias serviram para informar sobre o ambiente da primeira montagem, principalmente no que se refere aos figurinos que, no entanto, não foram criados com o objetivo de reproduzir os figurinos originais. E, sobretudo, para atiçar o imaginário de todos os envolvidos no processo.

Os testemunhos orais ou escritos sobre a dança, para Bernard (2001), correm o risco de submeter a dança à lógica da linguagem oral ou escrita, pois, desejando memorizá-la, a palavra e a escrita integram a dança ao seu próprio funcionamento semântico e a metamorfoseiam em objeto legível e interpretável. Ao longo da recriação de Um Berro Gaúcho, tivemos encontros com Gilson Petrillo, bailarino que participou da primeira versão da coreografia, e com Toneco, uma dos compositores da trilha musical. Seus depoimentos, mediados e comentados pela própria Eva Schul, foram centrados na exposição dos procedimentos de criação da coreografia e da música e nas condições de trabalho dos bailarinos na época. A utilização dos testemunhos e mesmo de fragmentos de movimentos e de gestos lembrados por Gilson Petrillo e por Eva Schul não foi um fator limitante do processo de recriação. Ao contrário, essas lembranças serviram de referência para a criação das cenas e das sequências coreográficas, alimentando o imaginário dos bailarinos. Talvez esses procedimentos se aproximem das noções de tradições vividas/tradições vivas (THOMAS, 2003), nas quais a corporificação de experiências de temporalidades diversas permite conjugar tradição e inovação.

As outras duas coreografias - Hall of Mirrors e Catch ou como segurar um instante - foram registradas em vídeo nas suas primeiras versões, o que serviu como ponto de partida para sua reelaboração. Hall of Mirrors foi criada em 1986, em Curitiba, para o Grupo da Universidade Federal do Paraná. Nessa época, Eva Schul dirigia o Grupo de Dança da Fundação Teatro Guaíra/Pontifícia Universidade 
Católica do Paraná e era professora no Curso Superior de Dança da FTG/PUC-PR. Quando a coreógrafa retorna a Porto Alegre, em 1992, remonta Hall of Mirrors para os bailarinos da sua companhia, a Ânima Cia. de Dança. Em 1994, a coreografia é recriada pela bailarina e coreógrafa Luciana Paludo e por seu grupo - o Balé do INSA ${ }^{6}$ - de São Luiz Gonzaga (RS). Hall of Mirrors já foi dançada por diferentes intérpretes, em diferentes contextos. Para a sua recriação em 2010, contamos com o testemunho de Mônica Dantas, Eduardo Severino e Cibele Sastre, que haviam participado da versão de 1992, e de Luciana Paludo, que havia dirigido a montagem de 1994. Hall of mirrors é baseada na letra da música homônima, do Grupo Kraftwerk $^{7}$ (Alemanha), concebida como uma representação de um jogo de espelhos. A coreografia é dançada por sete bailarinos, cada um manipulando uma estrutura feita de tubos de PVC que representam espelhos. Ela traz referências marcantes da época em que foi criada, seja em função da música, seja em função da utilização do espaço, do desenho de luz e dos figurinos. Talvez essa tenha sido a obra cuja remontagem esteve mais próximo do que Thomas (2003) chama de reconstrução.

\footnotetext{
$6 \quad$ O Ballet do INSA (Instituto Nossa Senhora Auxiliadora) foi criado por Luciana Paludo em 1992, em São Luiz Gonzaga, cidade localizada na região das Missões, noroeste do estado do Rio Grande do Sul. Esteve em atividade até o ano de 2000.

Grupo musical alemão que inventou um estilo de música techno tocada inteiramente por meio de sintetizadores.
} 


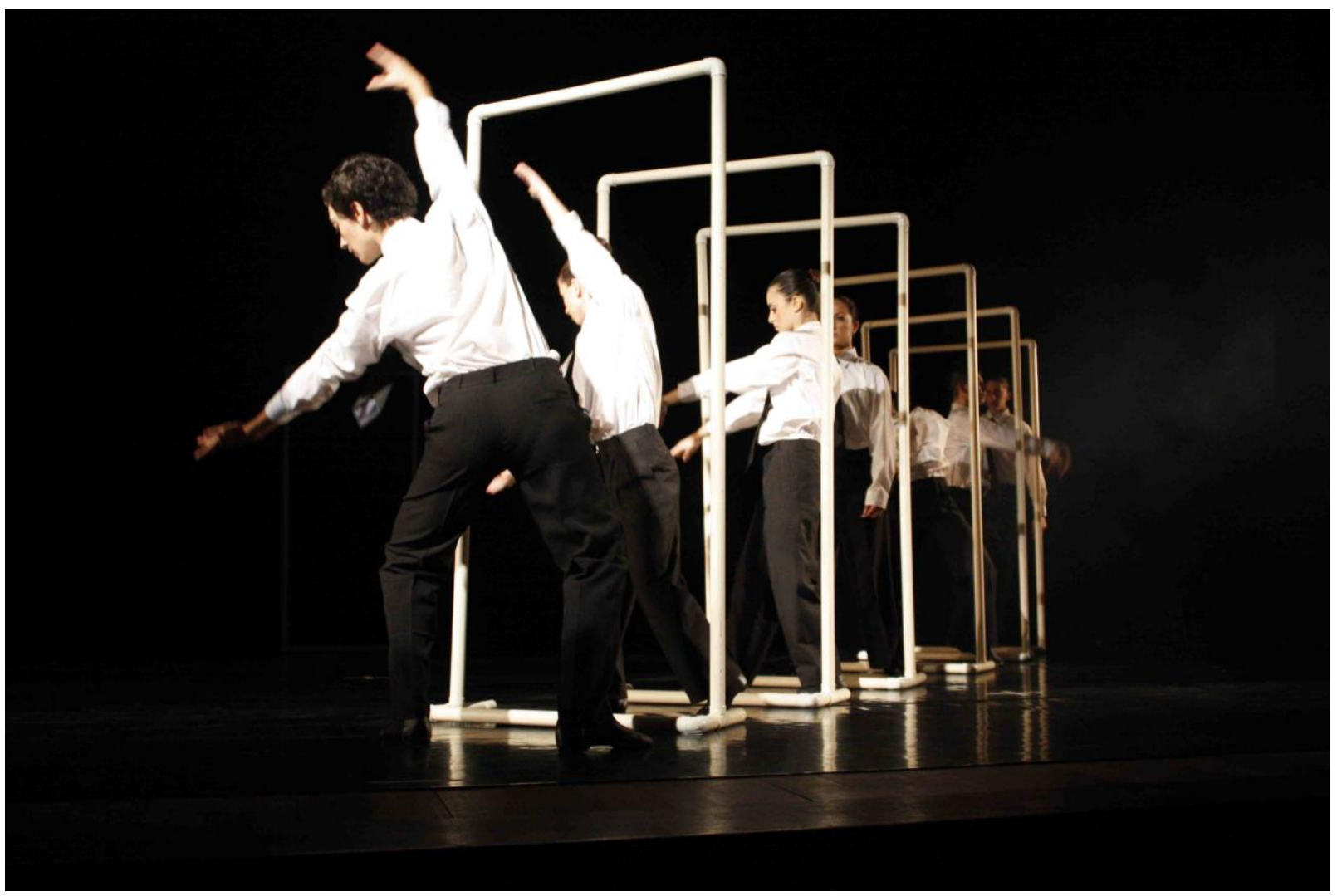

Hall of Mirrors, coreografia de Eva Schul. Projeto Dar carne à memória. Fotografia: Sofia Schul.

Para a remontagem de Catch ou como segurar um instante, contamos com a colaboração da bailarina e coreógrafa Viviane Lencina, que participou de Catch como criadora e intérprete, em 2002. A metodologia de recriação dessa obra se pautou num estudo apurado do gesto coreográfico, baseado tanto na análise dos registros em vídeo, quanto nos traços ainda presentes no corpo e no imaginário de Eva Schul e de Viviane Lencina. Catch foi criada a partir de pesquisas relacionadas com as mais variadas possibilidades de equilíbrio, desequilíbrios e apoios. Nesse sentido, para além de tentar reproduzir os movimentos que viam no vídeo, os bailarinos precisavam recriar nos seus corpos as possibilidades de equilíbrio, 
desequilíbrio e apoio demandadas na coreografia. Catch teve trilha musical especialmente composta por Celau Moreira.

Bernard (2001) chama atenção para os limites de utilização do vídeo. Apesar de o vídeo parecer uma reprodução mais fiel ou um traço relativamente mais claro para recriação de uma dança, à medida que pretende restituir a totalidade do movimento, o processo de sua execução, suas qualidades e suas posições no espaço, ele também apresenta limites. No entanto, por seus procedimentos de enquadramento e pelas características intrínsecas à temporalidade de captação das imagens, o vídeo não pode verdadeiramente memorizar a performance enquanto tal, mas somente inventar um jogo e uma configuração de perspectivas que obedece às escolhas de uma estratégia de dispositivo e de modalidade de filmagem e montagem que sobrepõem um recorte próprio da temporalidade e da existência.

Na recriação de Hall of Mirrors e de Catch ou como segurar um instante, o ponto de partida foram os registros em vídeo das primeiras versões das coreografias. Em momento posterior, os bailarinos apresentaram à coreógrafa um esboço da coreografia. Manipulando com eles o material produzido, em conjunto com as assistentes, Eva Schul estruturou as obras. Assim, configurou-se um trabalho de cocriacão entre bailarinos, assistentes e coreógrafa, no qual os bailarinos apropriaram-se destas coreografias, impregnando-as de suas presenças. Assim, mesmo trabalhando a partir de traços ou evidências mais próximos às primeiras versões, os bailarinos trabalharam intensamente como cocriadores e intérpretes. 


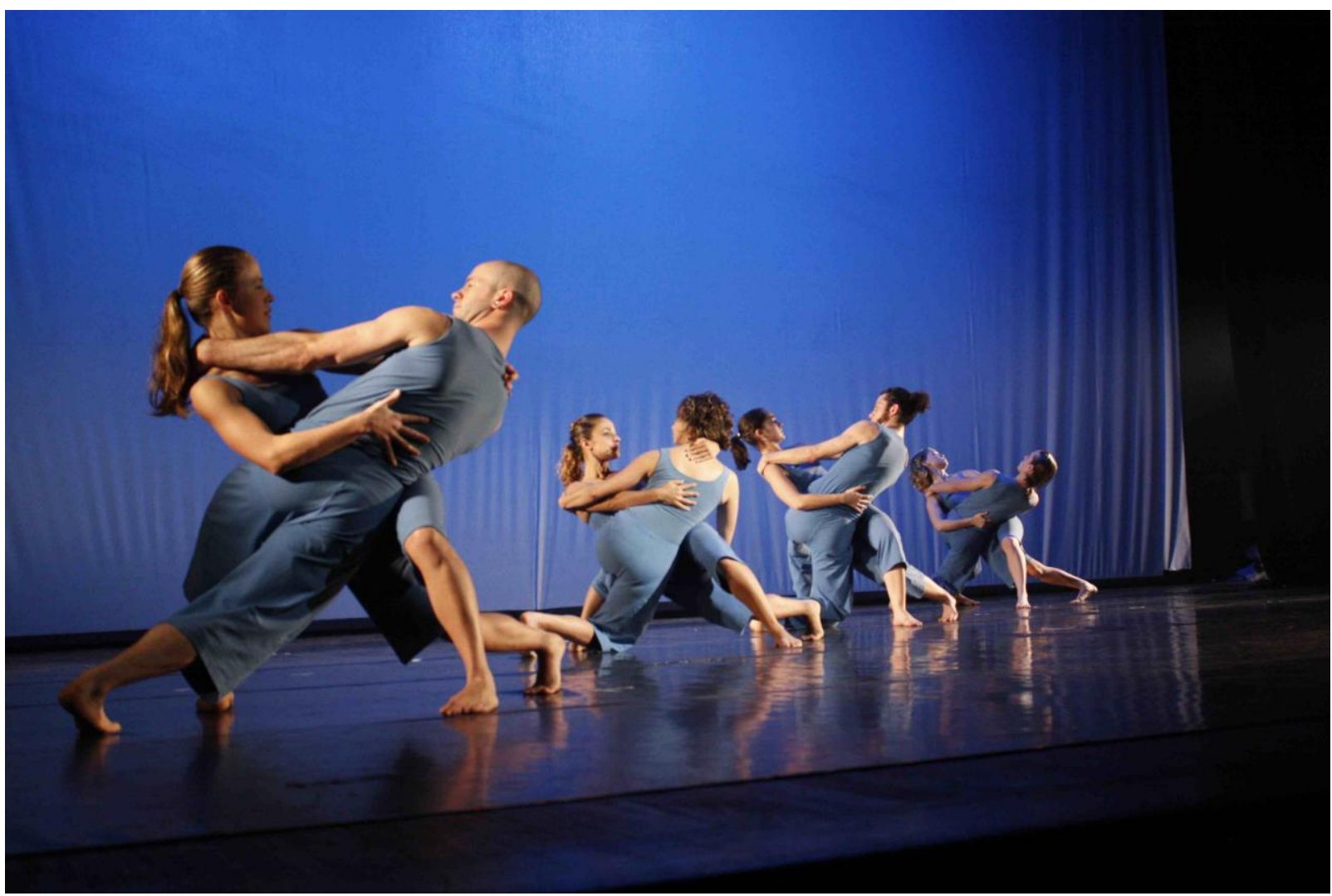

Figura 3: Catch, ou como segurar um instante, coreografia de Eva Schul. Projeto Dar carne à memória. Fotografia: Sofia Schul.

Um Berro Gaúcho, Hall of Mirrors e Catch ou como segurar um instante foram apresentadas no espetáculo Dar carne à memória I, em Porto Alegre, no Teatro Renascença, em maio de 2010. Foram assistidas por 550 pessoas $^{8}$.

8 Durante o ano de 2010, o Projeto Dar carne à memória realizou ainda o Seminário Preâmbulo às ações poéticas, com a presença da pesquisadora Cássia Navas, em março; o espetáculo Dar carne à memória II, em junho; e o espetáculo Dar carne à memória em agosto e setembro. O Projeto recebeu ainda o Prêmio Açorianos de Dança de melhor produção e Dar carne à memória I/ o de melhor espetáculo e o de melhor coreografia. O espetáculo Dar carne à memória participou do Festival Internacional de Artes Cênica Porto Alegre Em Cena. Estimamos que 1.400 pessoas participaram destes eventos. 


\section{Considerações}

Como ressalta Bernard (2001), parece que o desejo de memória da dança, sua recriação para um segundo gozo e sua transmissão pedagógica sob qualquer forma que seja, implicam senão sua autodestruição, ao menos sua perversão como produção de um estranho artefato que não possui outra temporalidade que aquela de seu modo específico de conservação, de lembrança e de enunciação. É por isso, paradoxalmente, que a dança só pode deixar ecos duráveis em nós, aceitando ser esquecida através dessas metamorfoses suscitadas por nosso desejo:

Nosso desejo de memória da dança porta em si a efígie da sua própria vacuidade e vaidade. Dito de outro modo, querendo restituir o ser da dança que não é obscuramente uma aparição efêmera, nossa consciência faz surgir a aparência fugitiva e precária da sua própria busca: o desejo de memória emudece em ilusória memória de um desejo (p. 221).

Reconhecendo as limitações dessas tentativas de se dar carne à memória e tentando não cair no memorialismo exacerbado, que, segundo Cunha (2008), "é um gênero mais dado à expansão do que à contenção e mais propenso a ceder a impulsos celebrativos e exibicionistas" (p. 30), pretendemos seguir celebrando a obra de Eva Schul, procurando desfrutar de sua sabedoria e de sua generosidade. Pois orientando, formando e fomentando novos criadores, Eva Schul e a Ânima Companhia de Dança engendram um ambiente que tem permitido o surgimento e o amadurecimento de artistas cujas obras, ações e projetos vêm se constituindo em referenciais para a dança contemporânea. E ela reconhece isto:

Ah, é muito orgulho [ter formado gerações de artistas, de coreógrafos, de pessoas que estão fazendo a diferença na dança]. Eu acho que nada me realizou mais do que ser professora. Porque, 
mesmo como coreógrafa, eu fui professora, e o fato de ter sempre alimentado essa participação dos bailarinos fez com que eles aprendessem a ser criadores. Fez com que eles aprendessem que criar não é repetir aquilo que eles conhecem. Acho que hoje é uma das coisas que mais me orgulha na vida. Acho que fui uma mestra, nisso eu me considero especial, não como coreógrafa. Acho que minha coreografia é boa nessas medidas, em trazer algo de inovador, em alimentar a criação coletiva, mas principalmente ela educou uma porção de pessoas a buscar mais. [...] Faz muita diferença que cada um desses coreógrafos esteja caminhando com suas próprias pernas em busca de algo muito mais inovador do que aquilo que aprendeu comigo. Não tem recompensa maior. (citada por SANTOS, 2004).

Um dos nossos desejos com o Projeto Dar carne à memória foi justamente o de compartilhar com bailarinos em formação esta oportunidade de conviver e de aprender com Eva Schul alguns modos de se fazer dança. Assim, Alessandro Rivelino, Bibiana Altenbernd, Cláudia Dutra, Everton Nunes, Fernanda Boff, Fernanda Santos, Gabriela Santos, Igor Ferraz Pretto, João Lima, Julia Ludke, Juliana Rutkowski, Lícia Arosteguy, Luciana Hoppe, Luiza Moraes, Maíra Meimes e Paola de Vasconcelos também já fazem parte da história da Ânima Cia. de Dança e de sua coreógrafa.

\section{Referências}

BANNES, Sally. Terpsichore in Sneakers: Post-Modern Dance. Hanover: Wesleyan University Press, 1987.

BERNARD, Michel. De la créatrion choregraphique. Pantin: Centre national de la danse, 2001. 
CUNHA, Maria Teresa Santos. Memória, história, biografia: escritas do eu e do outro, escritas da vida. In PEREIRA, Roberto; MEYER, Sandra; NORA, Sigrid (Org.). Seminários de dança: história em movimento: biografias e registros em dança. Caxias do Sul: Lorigraf, 2008, p. 29-37.

CUNHA, Morgada; FRANCK, Cecy. Dança: nossos artífices. Porto Alegre: Movimento, 2004.

DANTAS, Mônica. De que são feitos os dançarinos de "aquilo...": criação coreográfica e formação de intérpretes em dança contemporânea. Movimento, v.11, n. 2, p. 31-57, maio/agosto de 2005.

DANTAS, Mônica. Dança, o enigma do movimento. Porto Alegre: Editora da Universidade/UFRGS, 1999.

GINOT, Isabelle; MICHEL, Marcelle. (Ed.). La danse au XX siècle. Paris: Bordas, 1995.

IZQUIERDO, Ivan Antonio. Tempo e tolerância. Porto Alegre: Ed. da Universidade/UFRGS, 1998.

LAUNAY, Isabelle. "L'aprés midi d'un faune” et Quatuor Knust “... d'un faune (éclats)". Mouvement.net, le site indiscipliné, 01 de jan. 2000. Disponível em http://www.mouvement.net/html/fiche.php?doc to load=2. Acessado em 23 de abril de 2012.

MAIN, Lesley. The Dances of Doris Humphrey: Creating a contemporary perspective through directorial interpretation. Dance Research, vol. 23.2, 2005. Disponível em http://www.dorishumphreyfoundationuk.co.uk/archive/. Acessado em 25 de abril de 2010. 
Panorama de Dança 2007: 13 coreografias preenchem o domingo. Idança.net. 11 nov. 2007. Disponível em idanca.net/lang/pt-br/2007/11/11/panorama-de-danca2007-13-coreografias-preenchem-o-domingo/5090. Acessado em 25 de abril de 2012.

PASSERON, René. La poïétique. In BETLOUR, R. (Org.) Recherches poïétiques. Paris: Klincksieck, 1974, p. 11-23.

SANTOS, Katia Kalinka Alves. Um olhar sobre três obras. 2004. Monografia (Especialização). Pontifícia Universidade Católica do Rio Grande do Sul, 2004.

SCHUL, Eva. Memorial. Material não publicado, 2007.

THOMAS, Helen. The Body, Dance and Cultural Theory. Hampshire: Palgrave Macmillan, 2003.

\section{Créditos das imagens}

"berrosofia4": Um berro gaúcho, coreografia de Eva Schul. Projeto dar carne à memória. Fotografia: Sofia Schul.

"hallsofia14": Hall of Mirrors, coreografia de Eva Schul. Projeto dar carne à memória. Fotografia: Sofia Schul.

"catchsofia1": Catch, ou como segurar um instante, coreografia de Eva Schul. Projeto dar carne à memória. Fotografia: Sofia Schul. 